\title{
En stor og vigtig indsats
}

\author{
Dansk Idræts-Forbund v/tidl. generalsekretær, Emanuel Rose
}

Dansk Idræts-Forbund hilser ganske naturligt stiftelsen af det nye idrætshistoriske selskab velkommen.

Idrætten i moderne tid her i Danmark er langt over 100 år gammel, og dens historie er så værdifuld og interessant, at det ville være synd, hvis ikke den blev bevaret for eftertiden.

Hvis man hidtil har ønsket at vide noget om dansk idræts historie, har man været henvist til at søge mange steder, for naturligvis findes der en masse materiale om dette emne. Det har dog været svært at få en samlet oversigt over dette, men inden for det nye idrætshistoriske selskab vil der sikkert med årene blive rådet bod på dette, således at det vil blive adskilligt lettere at sætte sig ind $\mathrm{i}$, hvad der egentlig er sket.

Idrætshistorie er jo ikke blot gennemgang af en resultatmæssig udvikling inden for de enkelte specialidrætter. Det er nok så meget at finde frem til idrættens placering gennem tiderne i vort samfund, baggrunden for stillingtagen til aktuelle situationer, indsatsen for diverse holdninger og strømninger i samfundet. Og så repræsenterer idrætten jo et persongalleri, som de færreste andre bevægelser kan hamle op med $i$ antal.

Hvem var alle de ledere, der har været med til at præge dansk idræt? Hvor kom de fra? Hvad fik dem til at yde så store frivillige indsatser for idrætten og derigennem for idrætsungdommen? Mange er forlængst gået bort, men minderne om deres virke findes fortsat gemt $i$ arkivalier $i$ foreninger, $i$ forbund, hvor man fra jubilæumsskrifter, forhandlingsprotokoller m.m. vil kunne tegne nogle realistiske portrætter af disse idrættens store - men ofte uden for den snævre kreds - anonyme skikkelser.

Endnu lever der medarbejdere og aktive idrætsudøvere, der kan give værdifulde oplysninger, men det er på høje tid, at deres viden bliver indsamlet og registreret, så den kan bevares for eftertiden. Her tror jeg, at idrætshistorisk selskab vil kunne gøre en stor indsats.

Hvis man fra starten prioriterer de ting først, der ikke tåler at udsættes, så vil meget være nået.

Også tankerne om et idrætsmuseum er naturligvis værd at gøre noget ved. Der findes rundt om $\mathrm{i}$ landet mange værdifulde ting, der kan vise os 
udviklingen inden for idrætten. Nogle effekter står gemt langt af vejen, ja, er måske helt glemte, men en opfordring til at gå lofter, kældre, magasiner igennem, spørge hos tidligere ledere o.l. vil givet bringe mangt for dagen, som det er værd at samle på et mere tilgængeligt sted til glæde for interesserede og til gavn for dem, der vil forske også i denne del af idrættens historie.

Tak til initiativtagerne-DIF medvirker gerne. 